Adams, Jessica L.; Tipping, Edward; Bryant, Charlotte L.; Helliwell, Rachel C.; Toberman, Hannah; Quinton, John. 2015. Aged riverine particulate organic carbon in four UK catchments. Science of the Total Environment, 536. 648654. 10.1016/j.scitotenv.2015.06.141

(C) 2015 Elsevier B.V.

This manuscript version is made available under the CC-BY-NC-ND 4.0 license http://creativecommons.org/licenses/by-nc-nd/4.0/ (cc) EY-NC-ND

This version available http://nora.nerc.ac.uk/511976/

NERC has developed NORA to enable users to access research outputs wholly or partially funded by NERC. Copyright and other rights for material on this site are retained by the rights owners. Users should read the terms and conditions of use of this material at http://nora.nerc.ac.uk/policies.html\#access

NOTICE: this is the author's version of a work that was accepted for publication in Science of the Total Environment. Changes resulting from the publishing process, such as peer review, editing, corrections, structural formatting, and other quality control mechanisms may not be reflected in this document. Changes may have been made to this work since it was submitted for publication. A definitive version was subsequently published in Science of the Total Environment, 536. 648-654. 10.1016/i.scitotenv.2015.06.141

www.elsevier.com/ 


\section{Aged riverine particulate organic carbon in four UK catchments}

4 Jessica L. Adams ${ }^{\mathrm{a}}$, Edward Tipping ${ }^{\mathrm{a} *}$, Charlotte L. Bryant ${ }^{\mathrm{b}}$, Rachel C. Helliwell ${ }^{\mathrm{c}}$, 5 Hannah Toberman ${ }^{\mathrm{a}, \mathrm{d}}$, John Quinton ${ }^{\mathrm{e}}$

$6 \quad{ }^{a}$ Centre for Ecology and Hydrology, Lancaster Environment Centre, Lancaster, LA1 4AP

$7 \quad$ b NERC Radiocarbon Facility, East Kilbride, Scotland, G75 OQF

$8 \quad{ }^{\mathrm{c}}$ The James Hutton Institute, Craigiebuckler, Aberdeen, AB15 8QH, Scotland, UK

$9 \quad{ }^{\mathrm{d}}$ School of Environmental Sciences, University of Liverpool, Liverpool, L69 3GP

e Lancaster Environment Centre, Lancaster University, Lancaster, LA1 4YQ

Professor Edward Tipping Centre for Ecology and Hydrology

Lancaster Environment Centre

Lancaster

LA1 4AP

$\underline{\text { et } @ \text { ceh.ac.uk }}$

19

E-mail addresses:

21 jesams@ceh.ac.uk (J. Adams),et@ceh.ac.uk (E.Tipping), charlotte.bryant@glasgow.ac.uk

(C. Bryant), hannahtoberman@hotmail.com (H. Toberman), j.quinton@lancaster.ac.uk (J.

Quinton), rachel.helliwell@hutton.ac.uk (R. Helliwell) 


\section{ABSTRACT}

The riverine transport of particulate organic matter (POM) is a significant flux in the carbon cycle, and affects macronutrients and contaminants. We used radiocarbon to characterise POM in 9 rivers of four UK catchments (Avon, Conwy, Dee, Ribble) over a one-year period. Highdischarge samples were collected on three or four occasions at each site. Suspended particulate matter (SPM) was obtained by centrifugation, and the samples were analysed for carbon isotopes. Concentrations of SPM and SPM organic carbon (OC) contents were also determined, and were found to have a significant negative correlation. For the 7 rivers draining predominantly rural catchments, $\mathrm{PO}^{14} \mathrm{C}$ values, expressed as percent modern carbon absolute (pMC), varied little among samplings at each site, and there was no significant difference in the average values among the sites. The overall average $\mathrm{PO}^{14} \mathrm{C}$ value for all 7 sites of 91.2 $\mathrm{pMC}$ corresponded to an average age of $680{ }^{14} \mathrm{C}$ years, but this value arises from the mixing of differently-aged components, and therefore significant amounts of organic matter older than the average value are present in the samples. Although topsoil erosion is probably the major source of the riverine $\mathrm{POM}$, the average $\mathrm{PO}^{14} \mathrm{C}$ value is appreciably lower than topsoil values (which are typically $100 \mathrm{pMC}$ ). This is most likely explained by inputs of older subsoil OC from bank erosion, or the preferential loss of high- ${ }^{14} \mathrm{C}$ topsoil organic matter by mineralisation during riverine transport. The significantly lower average $\mathrm{PO}^{14} \mathrm{C}$ of samples from the River Calder (76.6 pMC), can be ascribed to components containing little or no radiocarbon, derived either from industrial sources or historical coal mining, and this effect is also seen in the River Ribble, downstream of its confluence with the Calder. At the global scale, the results significantly expand available information for $\mathrm{PO}^{14} \mathrm{C}$ in rivers draining catchments with low erosion rates.

Keywords: Particulate organic carbon, Radiocarbon, Rivers, Soils

Abbreviations: AMS, accelerator mass spectrometry; NRCF, NERC Radiocarbon Facility; OC organic carbon; pMC, percent modern carbon absolute; POC, particulate organic carbon; POM, particulate organic matter; $\mathrm{PO}^{14} \mathrm{C}$ particulate organic radiocarbon; SPM suspended particulate matter; [SPM] concentration of SPM 


\section{Introduction}

Particulate organic matter (POM) transported by rivers is defined as organic matter that does not pass a filter with sub-micron pore size, and mainly comprises allochthonous inputs from plant litter, soils and wastes, autochthonous phytoplankton and macrophyte debris, and in situ production from dissolved organic matter (Ittekot and Laane, 1991). It plays a significant role in the carbon cycle, being a loss from the terrestrial environment, a source of $\mathrm{C}$ to the atmosphere due to decomposition during transit, and ultimately a gain to the marine environment (Raymond and Bauer, 2001; Rosenheim and Galy, 2012; Worrall et al., 2014). Particulate organic carbon (POC) accounts for approximately $50 \%$ of the riverine global organic carbon export of 0.4 Pg a ${ }^{-1}$ (Schlünz and Schneider, 2000; Aufdenkampe et al., 2011). Particulate organic matter also governs the transport of the macronutrients nitrogen and phosphorus (Meybeck 1982, Walling 2005), metals (Tipping et al., 1997) and organic contaminants (Foster et al., 2000). To understand and quantify these POM-associated processes, and thereby predict how they might respond to changes in land use, climate and other environmental drivers, we need to delineate the sources of POM in different systems.

Because POM is part of suspended particulate matter (SPM), information about sources can be obtained from more general investigations into SPM, which is known to comprise a mixture of terrestrial material derived from both surface and sub-surface materials including bedrock and mineral soil (Blair et al., 2003). The SPM entering the river systems is generally the result of physical weathering and physical disturbance through anthropogenic activity. Sediment sourcing techniques, including mineralogy (Klages and Hsieh, 1975), chemistry (Gaillardet et al., 1999), magnetism (Gruszowski et al., 2003) and radionuclides (Estrany et al., 2010, Lu et al., 2014; Rosenheim and Galy, 2012) identify sources of SPM as being primarily topsoil and sub-surface material including erosion of exposed banks. Walling (2013) summarized sediment source information on $84 \mathrm{UK}$ rivers, and showed that on average topsoil was the largest contributor of SPM, with relative contributions from surface material and channel banks contributing between $50 \%$ to $99 \%$ and $<50 \%$ respectively.

The organic matter components of SPM have been studied by a variety of analytical techniques and with stable isotopes and element ratios (da Cunha et al., 2000; Onstad et al., 2000; Kendall et al., 2001; Higueras et al., 2014) to obtain information on molecular structure and insight into the materials from which the POM is derived. Determination of the radiocarbon content of POM provides further information, not only on sources but also 
apparent age. Radiocarbon gives a measure of the time elapsed since $\mathrm{C}$ fixation into plants from the atmosphere, providing an understanding of the residence time of plant-derived $\mathrm{C}$ and losses of $\mathrm{C}$ through mechanisms including leaching and erosion (Trumbore, 2009). Naturally occurring atmospheric ${ }^{14} \mathrm{C}$ can be used for the measure of $\mathrm{C}$ turnover on the centennial and millennial timescale due to the natural radioactive decay process, while "bomb carbon" originating from atmospheric weapons testing in the mid- $20^{\text {th }}$ century, which almost doubled the atmospheric ${ }^{14} \mathrm{C}$ levels (Hua et al., 2013), provides information on decadal timescales. Radiocarbon has been used in studies of POM in rivers in North and South America (Raymond and Bauer, 2001, Bouchez et al., 2014), Asia (Hilton et al., 2008; Rosenheim and Galy 2012), Europe (Cathalot et al., 2013, Megens et al., 2001), and Africa (Marwick et al., 2015). Global $\mathrm{PO}^{14} \mathrm{C}$ (particulate organic radiocarbon) data documented by Marwick et al. (2015) shows that SPM in highly-eroding catchments is depleted in $\mathrm{PO}^{14} \mathrm{C}$ and low in OC (organic carbon).

The review of Marwick et al. (2015) shows that to date while there are many $\mathrm{PO}^{14} \mathrm{C}$ data for catchments with high sediment loads, there are relatively few for riverine $\mathrm{PO}^{14} \mathrm{C}$ in temperate, low-erosion European catchments and no known data for catchments of this kind in the UK. In the wider context, UK data may be of interest because UK soils tend to be rich in carbon, which may lead to differences from global averages. Therefore understanding UK sources should improve our ability to model the terrestrial-freshwater $\mathrm{C}$ cycle, and its role in transferring carbon to the atmosphere and ocean. To this end, we carried out a programme of sampling and analysis to determine the radiocarbon contents of POM from four differing UK catchments. Since SPM concentrations, and therefore POM transport, are elevated at high flow, we focused our sample collection on high-discharge events. To interpret the results, we made use of the extensive soil radiocarbon data available for the UK. 
111

112

113

114

115

116

117

118

119

120

121

122

123

124

125

126

127

128

129

130

131

132

133

134

135

136

137

\section{Methods}

\subsection{Field sites}

Table 1 provides information on the individual rivers and their catchments, and their locations are shown in Figure 1. Data on discharge and rainfall were taken from the National River Flow Archive (NRFA) (http://www.ceh.ac.uk/data/nrfa/ accessed January 2015) and Met Office (http://www.metoffice.gov.uk/industry/data/commercial/rainfall accessed March 2015) respectively. Catchment areas were obtained from the CEH River and Catchment Query and Extraction Layer (Racquel) (http://wlwater.ceh.ac.uk/racquel/ accessed March 2015). Geological information was provided by the British Geological Society online map (http://mapapps.bgs.ac.uk/geologyofbritain/home.html, accessed March 2015). Soil types for England and Wales were obtained using soil maps (scale 1:250 000). For the Dee catchments, soil information was obtained from The James Hutton Institute online soils map (http://sifss.hutton.ac.uk/SSKIB_Stats.php accessed March 2015). Land use data were obtained from the website http://digimap.edina.ac.uk/ (accessed March 2015).

The Ribble catchment is situated in north-west England and has a population density of 989 persons $\mathrm{km}^{-2}$. Two major sub catchments, the Rivers Hodder and Calder drain from the north and south of the catchment respectively. Unlike other tributaries of the Ribble, the Calder catchment contains extensive conurbations including Burnley and Blackburn, with a history of industrial and mining activity. The upper parts of the catchment are responsive to rainfall, exhibiting a flashy flow regime.

The River Conwy is one of the major drainage systems in North Wales. The catchment has a population density of 49 persons $\mathrm{km}^{-2}$. The topography is largely mountainous, giving a high river response during storm events.

Situated in the south of England, the Hampshire Avon catchment has a population density of 108 persons $\mathrm{km}^{-2}$. The catchment is largely groundwater dominated due to the presence of chalk aquifers. Thus, the system at the tidal limit does not significantly respond during rainfall events. 
Table 1. Catchment information. Discharge data are from records of between 35 and 50 years up to the present. Geology, soil type and land use are presented in order of importance.

\begin{tabular}{|c|c|c|c|c|c|c|c|c|c|}
\hline & Calder & Hodder & Ribble A & Ribble B & Conwy & Avon & Gairn & Dee A & Dee B \\
\hline Catchment drainage area $\left(\mathrm{km}^{2}\right)$ & 317 & 258 & 446 & 1144 & 365 & 1713 & 146 & 2039 & 2080 \\
\hline Altitude range (masl) & $50-560$ & $40-480$ & $20-420$ & $15-560$ & $10-1060$ & $4-240$ & $220-1100$ & $30-1220$ & $20-1220$ \\
\hline Mean annual rainfall (m) & 1.1 & 1.5 & 1.2 & 1.2 & 2.1 & 0.8 & 1.1 & 0.9 & 0.8 \\
\hline Mean annual air temperature $\left({ }^{\circ} \mathrm{C}\right)$ & 8.9 & 7.7 & 8.8 & 8.6 & 8.4 & 9.6 & 5.1 & 7.6 & 7.7 \\
\hline \multicolumn{10}{|l|}{ River discharge $\left(\mathrm{m}^{3} \mathrm{~s}^{-1}\right)$} \\
\hline mean & 8.6 & 8.8 & 13.5 & 33.2 & 18.9 & 20.2 & 3.9 & 47.0 & no data \\
\hline $95 \%$ exceedance & 1.9 & 1.1 & 1.1 & 4.6 & 1.4 & 6.2 & 0.8 & 8.7 & no data \\
\hline $10 \%$ exceedance & 19.5 & 22.0 & 34.4 & 81.2 & 45.8 & 39.0 & 7.4 & 94.6 & no data \\
\hline \multirow[t]{3}{*}{ Principal bedrock geology ${ }^{a}$} & $\mathrm{CM}$ & MG & MG & MG & SSM & $\mathrm{Ch}$ & Ig & VS & VS \\
\hline & MG & SSM & $\mathrm{CM}$ & $\mathrm{CM}$ & $\mathrm{SC}$ & $\mathrm{SSC}$ & VS & Ig & Ig \\
\hline & & $\mathrm{L}$ & SSM & SSM & & & & & $\mathrm{N}$ \\
\hline \multirow[t]{3}{*}{ Principal soil types ${ }^{\mathrm{b}}$} & CS & $\mathrm{CS}$ & $\mathrm{Sg}$ & $\mathrm{Sg}$ & $\mathrm{Pz}$ & $\mathrm{Rz}$ & $\mathrm{P}$ & $\mathrm{BE}$ & $\mathrm{BE}$ \\
\hline & $\mathrm{U}$ & SP & $\mathrm{CS}$ & CS & SHG & SG & Gs & $\mathrm{Rz}$ & $\mathrm{Rz}$ \\
\hline & A & $\mathrm{BE}$ & A & A & $\mathrm{SG}$ & SP & $\mathrm{BE}$ & $\mathrm{A}$ & A \\
\hline \multirow[t]{3}{*}{ Principal land cover ${ }^{c}$} & IG & B & IG & IG & IG & IG & MH & $\mathrm{H}$ & MH \\
\hline & $\mathrm{U}$ & $\mathrm{HG}$ & $\mathrm{B}$ & $\mathrm{U}$ & $\mathrm{B}$ & $\mathrm{W}$ & $\mathrm{H}$ & HG & $\mathrm{H}$ \\
\hline & & IG & HG & B & $\mathrm{AG}$ & SU & $\mathrm{B}$ & MH & HG \\
\hline
\end{tabular}

Ch chalk, CM coal measures, Ig igneous intrusion, L limestone, MG millstone grit, N Neogene rocks - gravel sand silt and clay, SC sandstone and conglomerate, SSC sand silt and clay, SSM sandstone siltstone mudstone, VS volcanic and sedimentary rock.

${ }^{\mathrm{b}}$ Key to soil type:

A alluvisol, BE brown earth, CS cambic stagnogley, Gs gleysol, P peat, Pz podzol, Rz rendzina, SG stagnogley, SHG stagnohumic gley, SP stagnopodzol, U urban,

${ }^{\mathrm{c}}$ Key to land cover:

AG acid grassland, B bog, H heathland, HG heather grassland, IG improved grassland, MH, montane heathland, SU suburban, $\mathrm{U}$ urban, $\mathrm{W}$ woodland 

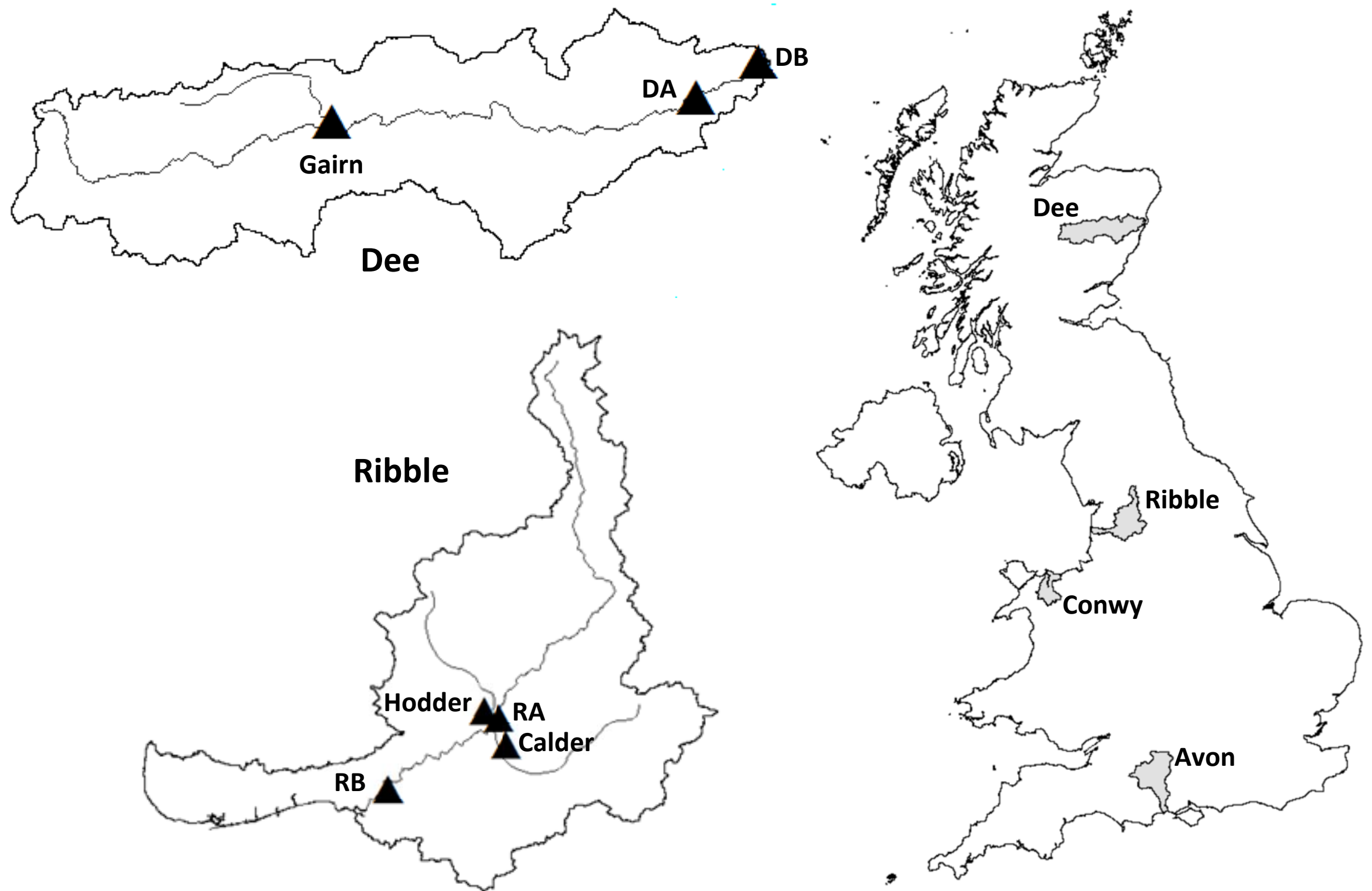

Figure 1. Location map showing the study catchments. For the Dee and Ribble, black triangles indicate sampling sites. The Avon and Conwy sampling sites were at the tidal limits. 
The River Dee catchment is situated in the north-east of Scotland. The catchment is

159

160

161

162

163

164

165

166

167

168

169

170

171

172

173

174

175

176

177

178

179

180

181

182

183

184

185

186

187

188

189

sparsely populated above the tidal limit, with a population density of 4 persons $\mathrm{km}^{-2}$. The tributary of the River Gairn is situated in the upper western reaches of the catchment. The upper mountainous areas respond rapidly to rainfall and snowmelt, producing a flashy flow regime.

\subsection{Sampling and analysis}

To minimise risk of carbon contamination, all equipment used during sampling and processing was new or acid-washed and all samples were managed in a radiocarbon tracer-free laboratory. Water samples (5 L) were collected in high-density polyethylene containers from the tidal limit of the four main catchments, and additional upstream samples were taken in the Ribble and Dee catchments (Figure 1). For the Ribble, Conwy and Dee sites samples were collected during high-flow events. For the Avon, which has a much less flashy flow regime, they were taken at regular intervals throughout one year. High flow events were identified from daily river levels measured at gauging stations near the sampling sites, and made available on-line by the Environment Agency of England and Wales and the Scottish Environment Protection Agency. During the period October 2013 - October 2014, four samples were taken for most of the sites, but only three each at the Gairn and Dee A sites. Additional 500 or 1000 $\mathrm{mL}$ samples were collected for the determination of SPM concentration and the carbon content of the SPM.

The SPM was extracted from the water samples through repeated centrifugation $(6 \times$ $500 \mathrm{~mL}$ rotor spinning at $10000 \mathrm{rpm}$ for 30 minutes), removal of supernatant and pooling, until approximately $100 \mathrm{~mL}$ of suspended sediment and water remained. To ensure the absence of inorganic carbonate, the concentrated suspended sediment was acidified by adding $400 \mathrm{~mL}$ of $1 \mathrm{M} \mathrm{HCl}$ to the extracted sediment and left overnight. Samples were then twice rinsed and centrifuged with deionised water, and sub-sampled for radiocarbon analysis. Remaining sediment was frozen for further analysis.

Organic carbon content of the SPM was measured using two different techniques. Firstly a known volume of the additional water sample was filtered through a pre-weighed, precombusted $\left(500^{\circ} \mathrm{C}\right)$ Whatman $\mathrm{GF} / \mathrm{F}$ filter paper. This was dried at $105^{\circ} \mathrm{C}$ overnight and reweighed to determine [SPM], then analysed for total carbon with a Vario EL elemental analyser at CEH Lancaster (Ribble, Conwy, Avon) and a Thermo Flash 2000 elemental analyser at the James Hutton Institute. The values obtained would include any inorganic carbon present in the samples. Secondly a sub-sample of the concentrated SPM was captured on a 
pre-weighed and combusted GF/F filter paper, and analysed. Results obtained by the two methods were in good agreement, suggesting that little or no inorganic carbonate had been present in the samples. Reported values are means from the two methods.

Graphite targets for ${ }^{14} \mathrm{C}$ analysis by AMS were prepared by quantitative recovery of carbon in sealed quartz tubes followed by cryogenic separation of $\mathrm{CO}_{2}$ (Boutton et al., 1983). Aliquots of $\mathrm{CO}_{2}$ were converted to an iron/graphite mix by iron/zinc reduction (Slota et al., 1987). A sub-sample of $\mathrm{CO}_{2}$ was used to measure $\delta^{13} \mathrm{C}$ using a dual-inlet mass spectrometer with a multiple ion beam collection facility (Thermo Fisher Delta V) in order to correct ${ }^{14} \mathrm{C}$ data to $25 \% \delta^{13}$ CVPDB. The mass spectrometer was calibrated with international reference materials to a precision of $\pm 0.03 \%$. For five samples, difficulties were encountered in the measurement of ${ }^{13} \mathrm{C}$ by mass spectrometry, and so instead values of $\delta^{13} \mathrm{C}$ were obtained during AMS analysis, and used to correct to $\delta^{13} \mathrm{C}=-25 \%$ vPDB. In these cases the $\delta^{13} \mathrm{C}$ values were not considered representative of the original combusted material.

In all but three cases ${ }^{14} \mathrm{C}$ analysis was carried out at the Scottish Universities Environmental Research Centre AMS Laboratory, East Kilbride (Xu et al., 2004); these have publication codes starting SUERC. The other three measurements were on sample sizes of less than $500 \mu \mathrm{g}$ carbon and were made at the Keck Carbon Cycle AMS Laboratory at the University of California Irvine (publication codes UCIAMS). Size matched process background materials and known age standards were prepared and analysed to check accuracy and precision. In keeping with international practice, the results are reported as absolute $\%$ modern (pMC) which involves a mathematical adjustment to account for ongoing radioactive decay of the international reference standard (oxalic acid, provided by the US National Bureau of Standards), since AD 1950 (Stuiver and Polach, 1977) with conventional radiocarbon ages (based on radioactive decay and relative to AD1950) provided where results are below 100 pMC. The ${ }^{14} \mathrm{C}$ enrichment of a sample is measured as a percentage (or fraction) of the ${ }^{14} \mathrm{C}$ activity relative to the modern standard of oxalic acid where $100 \%$ modern is defined as the value in AD 1950, in the absence of any anthropogenic influences. Radiocarbon contents can exceed 100 pMC if they contain sufficient "bomb carbon". Overall analytical precision is quoted at $1 \sigma$.

\subsection{Soil radiocarbon data}


220 To aid the interpretation of the $\mathrm{PO}^{14} \mathrm{C}$ data, we assembled soil radiocarbon data for UK sites

221 under different land use. These comprised 70 data points for agricultural soils from Jenkinson

222 et al. (2008), 132 values for semi-natural non-forested and forested soils from Mills et al.

223 (2014), and 87 of our own unpublished data (H Toberman, JL Adams, E Tipping, CL Bryant)

224 for semi-natural sites and improved grassland. The results are summarised in Table S1. We

225 used values of ${ }^{14} \mathrm{C}$ (pMC) for samples taken over the time-period 1999 to 2013 . Average values

226 were calculated to simplify data presentation and provide an overall picture of radiocarbon with

227 depth. Because ${ }^{14} \mathrm{C}$ is constantly changing, albeit slowly, the combination of data taken in

228 different years involves approximation, but the time period for which data were taken was short

229 in comparison to the turnover rate of bulk soil carbon as estimated by Mills et al. (2014).

230 Therefore the averages obtained will differ little from those that would apply had all the 231 sampling been simultaneous. 
At a UK level, the study catchments vary with respect to size, altitude range, climate, soil type, and land use (Table 1). The Calder catchment stands out as the only one with a substantial urban area, and it is also industrialised. The Avon catchment differs in that it lacks upland area and has more cultivated land. Furthermore, the River Avon discharge varies relatively little, owing to the dominant influence of groundwater. The other rivers display much more flashy flow regimes. In the Avon, Conwy and Ribble catchments, the main land use is livestock grazing, mainly on improved grassland in the Avon and Ribble, but mainly on unimproved grassland or heather moorland in the Conwy. Much of the Dee catchment is heather moorland and blanket bog, with significant but smaller areas of coniferous plantation woodland and improved grassland. None of the catchments contains extensive arable agriculture. In all cases, the dominant soil types have organic-rich surface horizons.

High flow water samples collected across the catchments varied considerably in average [SPM] and OC content (Table 2). The OC content (\%) declines with increasing [SPM], the relationship following the power law, $\mathrm{OC}(\%)=26.7[\mathrm{SPM}]^{-0.22}$, which accounts for $75 \%$ of the variance in OC content $(\mathrm{p}<0.005)$. This is consistent with global-scale data collated by Marwick et al. (2015), and means that under conditions of high sediment delivery the SPM is relatively poor in OC.

The $\delta^{13} \mathrm{C}$ values of the samples (Table 3 ) fall in the range -30 to $-25 \%$, with all but one value $<-27 \%$. These indicate that the carbon is derived almost exclusively from plants using the $\mathrm{C}_{3}$ photosynthetic pathway, which is normal for northern temperate ecosystems like the UK (Still et al., 2003). The ${ }^{14} \mathrm{C}$ contents of the samples fell in the range 69-100 pMC, corresponding to conventional ${ }^{14} \mathrm{C}$ ages of 3000 years to modern (Table 3 ). The overall mean is $909{ }^{14} \mathrm{C}$ years with a standard deviation (SD) of 555 years. Comparison of the mean ${ }^{14} \mathrm{C}$ values for the individual rivers (Figure 2) shows that the only two rivers differing significantly from the others were the River Calder $(\mathrm{p}<0.01)$ and Ribble B site $(\mathrm{p}<0.001)$. The markedly low ${ }^{14} \mathrm{C}$ for the Calder is probably related to its urban and industrial character, and the contribution of the Calder flow to that of the Ribble B is likely the reason for the moderately low $\mathrm{PO}^{14} \mathrm{C}$ of the latter site. If the $\mathrm{PO}^{14} \mathrm{C}$ data for the Calder and Ribble $\mathrm{B}$ are ignored, the overall average $\mathrm{PO}^{14} \mathrm{C}$ value is $91.2 \mathrm{pMC}$ (SD 3.0), and the average age of POC becomes 681 ${ }^{14} \mathrm{C}$ years (SD 246 years), which can be taken as a representative value for predominantly rural rivers. 
264 To put the results into context, we can firstly consider the radiocarbon content of catchment 265 soils. A systematic survey of soil radiocarbon in proportion to land use or soil type is not 266 available for each catchment, but a substantial body of radiocarbon data (Table S1) can be used 267 to summarise land-use and depth variations for the UK (Figure 3). The results show that the 268 highest ${ }^{14} \mathrm{C}$ contents are found for topsoils under forest, then for soils under non-forest semi269 natural vegetation, then under agricultural land use. Sub-soil ${ }^{14} \mathrm{C}$ shows a fairly regular pattern 270 of decline with depth (Figure 3). The average riverine $\mathrm{PO}^{14} \mathrm{C}$ of $91.2 \mathrm{pMC}$ is lower than the 271 average soil organic ${ }^{14} \mathrm{C}$ values for forest and non-forest semi-natural topsoils, but only slightly 272 less than the improved grassland average of 93.6pMC, calculated from the two topsoil depths 273 of 7 and $11 \mathrm{~cm}$ in figure 3; note that none of our catchments included significant areas of arable 274 soil.

275 Secondly, our results can be compared with a global dataset published by Marwick et 276 al. (2015) (Figure 4). These authors identified [SPM] and the OC content (\%) of SPM as useful 277 variables against which to compare the ${ }^{14} \mathrm{C}$ values. In the global context, the UK [SPM] values 278 are comparably low and the $\mathrm{OC}$ contents are comparatively high. The $\mathrm{PO}^{14} \mathrm{C}$ values are high 279 compared with data for high-SPM, low-OC systems, but lower than the previously reported 280 data for the low-SPM, high-OC range. 
283 Table 2. Mean concentrations of SPM and OC contents of SPM. Values in brackets are 284 standard deviations, and reflect both natural variation and the averaging of results obtained by 285 different methods (Section 2.2).

286

\begin{tabular}{ccc}
\hline River & $\begin{array}{c}{[\mathrm{SPM}]} \\
\mathrm{mg} \mathrm{L}^{-1}\end{array}$ & $\begin{array}{c}\text { OC content } \\
\%\end{array}$ \\
\hline Calder & $52.8( \pm 63.2)$ & $8.8( \pm 4.7)$ \\
Hodder & $13.4( \pm 6.8)$ & $15.0( \pm 8.0)$ \\
Ribble A & $13.8( \pm 7.6)$ & $14.3( \pm 5.7)$ \\
Ribble B & $21.3( \pm 19.0)$ & $16.1( \pm 10.3)$ \\
Conwy & $2.7( \pm 1.0)$ & $24.6( \pm 10.3)$ \\
Avon & $8.1( \pm 5.4)$ & $19.1( \pm 6.3)$ \\
Gairn & $0.8( \pm 0.2)$ & $35.9( \pm 19.2)$ \\
Dee A & $0.8( \pm 0.5)$ & $14.4( \pm 14.2)$ \\
Dee B & $0.9( \pm 0.5)$ & $35.0( \pm 17.7)$ \\
\hline
\end{tabular}


288 Table 3. Isotope data for POM in high-flow samples. Values are given of ${ }^{14} \mathrm{C}(\mathrm{pMC}), \delta^{13} \mathrm{C}$ 289 (\%o vPDB) and conventional radiocarbon age (years BP). The errors in ${ }^{14} \mathrm{C}$ are expressed as $290+/-1 \sigma(\mathrm{pMC})$ where $\sigma$ is the overall analytical uncertainty. Bracketed values of $\delta^{13} \mathrm{C}$ are not 291 necessarily representative of the original combusted material (see Section 2.2).

292

\begin{tabular}{|c|c|c|c|c|c|c|}
\hline River & Date & $\delta^{13} \mathrm{C}$ & ${ }^{14} \mathrm{C}$ & $+/-1 \sigma$ & Age & Publication No. \\
\hline \multirow[t]{4}{*}{ Calder } & $4 / 10 / 13$ & -28.2 & 75.06 & 0.35 & 2243 & SUERC-52256 \\
\hline & $22 / 10 / 13$ & -27.5 & 68.86 & 0.30 & 2935 & SUERC-52262 \\
\hline & $2 / 1 / 14$ & -28.2 & 81.80 & 0.36 & 1552 & SUERC-52267 \\
\hline & $7 / 1 / 14$ & -28.5 & 80.58 & 0.37 & 1672 & SUERC-52274 \\
\hline \multirow[t]{4}{*}{ Hodder } & $4 / 10 / 13$ & -28.6 & 89.89 & 0.39 & 794 & SUERC-52257 \\
\hline & $22 / 10 / 13$ & -28.6 & 91.09 & 0.42 & 687 & SUERC-52263 \\
\hline & $2 / 1 / 14$ & -28.8 & 91.25 & 0.40 & 673 & SUERC-52268 \\
\hline & $7 / 1 / 14$ & $(-28.6)$ & 89.92 & 0.39 & 792 & SUERC-52275 \\
\hline \multirow[t]{4}{*}{ Ribble A } & $4 / 10 / 13$ & -25.2 & 88.95 & 0.41 & 878 & SUERC-52258 \\
\hline & $22 / 10 / 13$ & -28.6 & 87.67 & 0.40 & 995 & SUERC-52264 \\
\hline & $2 / 1 / 14$ & -29.1 & 89.55 & 0.41 & 825 & SUERC-52272 \\
\hline & $7 / 1 / 14$ & -29.3 & 89.26 & 0.41 & 850 & SUERC-52276 \\
\hline \multirow[t]{4}{*}{ Ribble B } & $4 / 10 / 13$ & -28.6 & 84.68 & 0.39 & 1274 & SUERC-52261 \\
\hline & $22 / 10 / 13$ & -28.6 & 84.68 & 0.39 & 1273 & SUERC-52265 \\
\hline & $2 / 1 / 14$ & -28.7 & 88.15 & 0.41 & 951 & SUERC-52273 \\
\hline & $7 / 1 / 14$ & -28.8 & 84.34 & 0.39 & 1306 & SUERC-52277 \\
\hline \multirow[t]{4}{*}{ Conwy } & $7 / 1 / 14$ & -28.5 & 90.52 & 0.42 & 737 & SUERC-52278 \\
\hline & $27 / 1 / 14$ & $(-23.0)$ & 90.09 & 0.28 & 775 & UCIAMS-144595 \\
\hline & $14 / 2 / 14$ & -29.2 & 97.90 & 0.49 & 108 & SUERC-53199 \\
\hline & $22 / 10 / 14$ & -28.3 & 100.07 & 0.47 & Modern & SUERC-58254 \\
\hline \multirow[t]{4}{*}{ Avon } & $22 / 10 / 13$ & -28.2 & 90.60 & 0.40 & 731 & SUERC-52266 \\
\hline & $6 / 2 / 14$ & $(-28.4)$ & 88.78 & 0.28 & 895 & UCIAMS-144596 \\
\hline & $23 / 4 / 14$ & -29.9 & 92.63 & 0.48 & 553 & SUERC-54377 \\
\hline & $28 / 8 / 14$ & -30.1 & 92.62 & 0.41 & 554 & SUERC-57317 \\
\hline \multirow[t]{3}{*}{ Gairn } & $7 / 1 / 14$ & -28.5 & 90.58 & 0.42 & 732 & SUERC-52283 \\
\hline & $26 / 2 / 14$ & $(-25.9)$ & 90.92 & 0.31 & 700 & UCIAMS-144597 \\
\hline & $16 / 3 / 14$ & -27.0 & 95.84 & 0.45 & 279 & SUERC-54379 \\
\hline \multirow[t]{3}{*}{ Dee A } & $7 / 1 / 14$ & -27.9 & 93.74 & 0.41 & 457 & SUERC-52282 \\
\hline & $26 / 2 / 14$ & -28.2 & 89.52 & 0.45 & 827 & SUERC-53201 \\
\hline & $21 / 3 / 14$ & -27.2 & 88.09 & 0.46 & 957 & SUERC-54382 \\
\hline \multirow[t]{4}{*}{ Dee B } & $7 / 1 / 14$ & -27.9 & 93.04 & 0.41 & 517 & SUERC-52281 \\
\hline & $26 / 2 / 14$ & $(-28.6)$ & 88.88 & 0.45 & 885 & SUERC-53200 \\
\hline & $16 / 3 / 14$ & -27.7 & 88.95 & 0.44 & 878 & SUERC-54378 \\
\hline & $21 / 3 / 14$ & -27.6 & 91.76 & 0.44 & 628 & SUERC-54383 \\
\hline
\end{tabular}


295

296

297

298

299

300

301

302

303

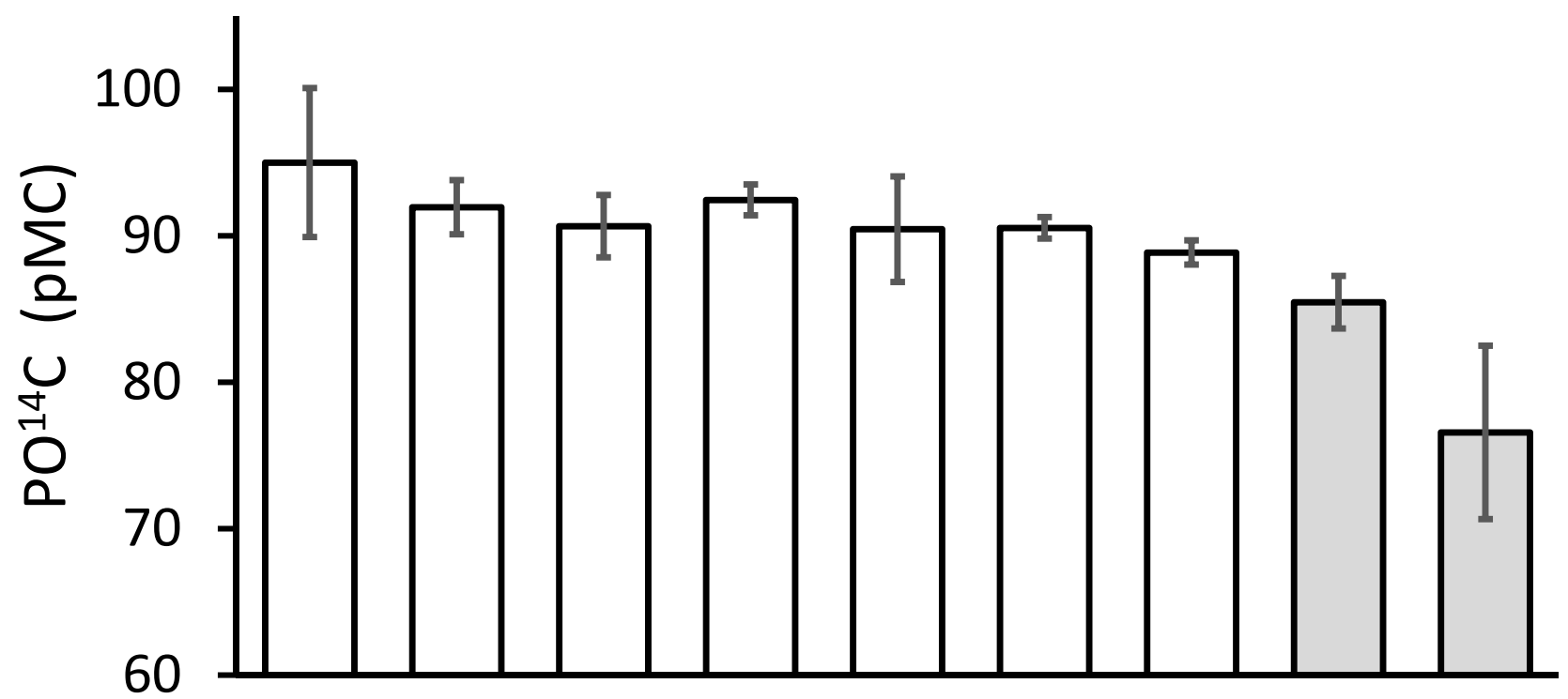

304

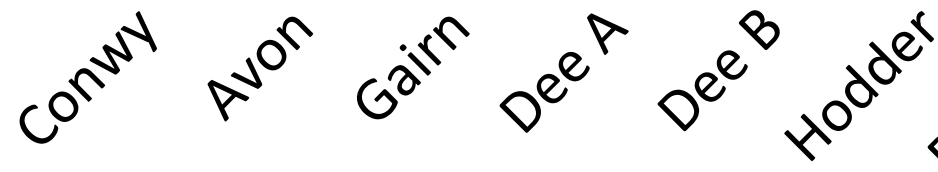

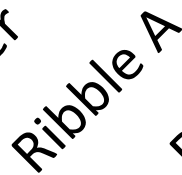<smiles>Cc1ccc(C)cc1</smiles><smiles>O=[Mg]</smiles>

305

Figure 2. Average $\mathrm{PO}^{14} \mathrm{C}(\mathrm{pMC})$ for suspended sediment collected at high flow at the 9 306 sampling sites. Error bars represent standard deviations. Greyed bars show the two sites for 307 which the $\mathrm{PO}^{14} \mathrm{C}$ values differ significantly from the others. 


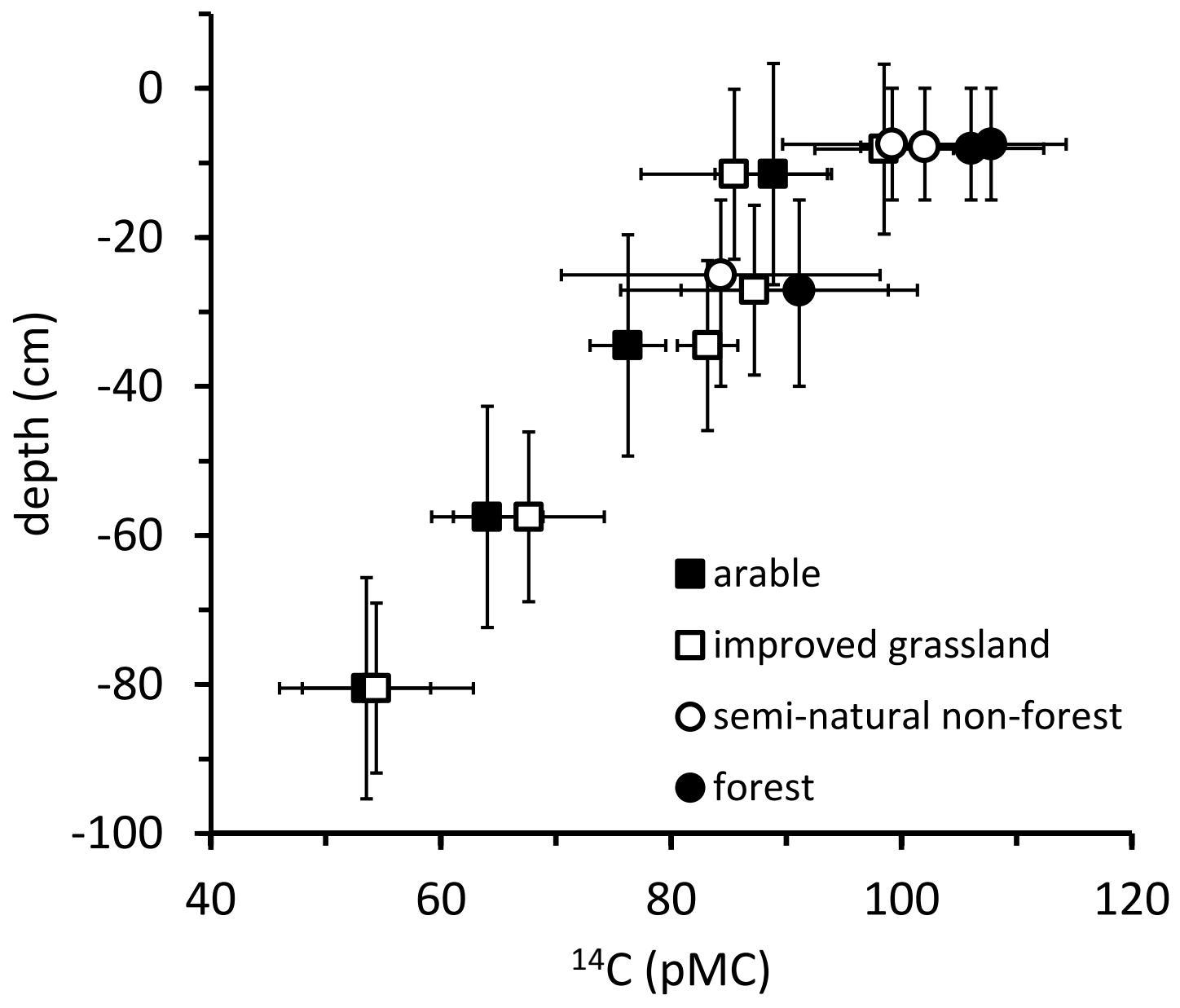

309

310

311 Figure 3. Soil radiocarbon plotted against soil depth for 296 samples of UK soils. Depths are 312 plotted as the weighted average of sampling depths. The horizontal bars are standard deviations 313 in ${ }^{14} \mathrm{C}$, the vertical bars are ranges of sampling depth. See Table $\mathrm{S} 1$ for details. 


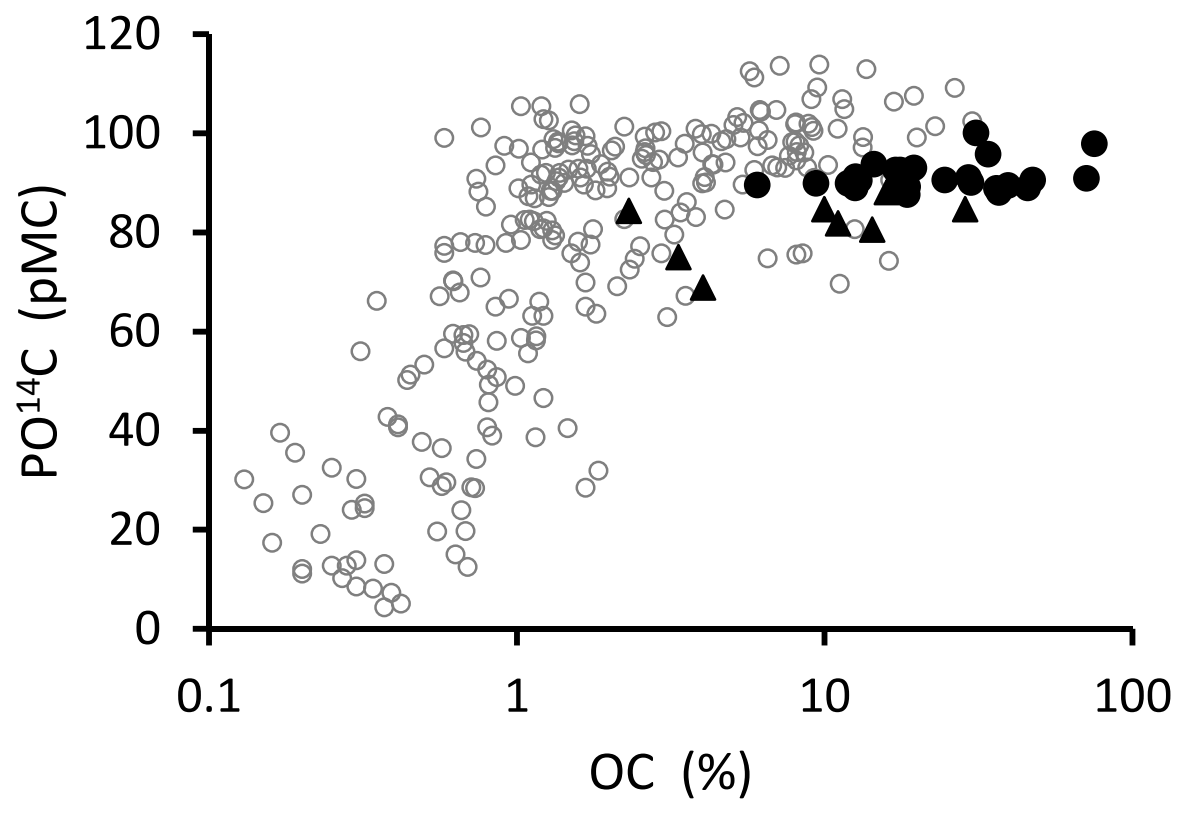

\section{8}

339 Figure 4. Radiocarbon contents of POM, i.e. $\mathrm{PO}^{14-} \mathrm{C}$, plotted the against OC content of SPM $340(\%)$ and [SPM]. Global data collated by Marwick et al. (2015) are represented by the open 341 circles. Data for the 7 rurally-dominated UK sites are shown by filled circles. Values for the 342 Rivers Calder and Ribble B are shown by filled triangles. 


\section{Discussion}

In attempting to interpret the $\mathrm{PO}^{14} \mathrm{C}$ data reported here, it must be borne in mind that all the measured values arise from the mixing of organic matter from different sources, and that any calculated ages are only apparent. Therefore, the mean of $680{ }^{14} \mathrm{C}$ years must mean that both younger and older material is also present. An especially clear effect of mixing is seen within the present data, for the River Calder sub-catchment and Ribble B site (Table 3, Figure 2). The Calder $\mathrm{PO}^{14} \mathrm{C}$ values $(68-82 \mathrm{pMC})$ are lower than at any of the other sites due to industrial and/or mining activity in the catchment; for example coal $\left({ }^{14} \mathrm{C} \sim 0\right)$ may be present in the samples. Mixing of River Calder water with water from the other two Ribble tributaries (Figure 1) then leads to relatively low $\mathrm{PO}^{14} \mathrm{C}(84-89 \mathrm{pMC})$ in the samples from the Ribble $\mathrm{B}$ site.

For the 7 rivers other than the Calder and Ribble $\mathrm{B}$, the average value of $\mathrm{PO}^{14} \mathrm{C}(91.2$ pMC) could arise from the mixing of topsoil material with material from subsoils, exposed at the bank or via field drains (Chapman et al., 2001, Deasy et al., 2009). For example, if we assume that average subsoil has a ${ }^{14} \mathrm{C}$ value of $75 \mathrm{pMC}$ (from Figure 3, the value at a depth of about $50 \mathrm{~cm}$ ), and adopt a mid-range value of $100 \mathrm{pMC}$ for the topsoil (Figure 3), then the value of $91.2 \mathrm{pMC}$ would arise from a mixture comprising $65 \%$ topsoil OC and $35 \%$ subsoil OC. But if a topsoil value of $95 \mathrm{pMC}$ were chosen, which might arise if soil under improved grassland were the main source of riverine POM (Figure 3), the mixture would be $81 \%$ topsoil OC and $19 \%$ subsoil OC. These results bracket the average contributions to riverine SPM of topsoil and subsoil (73\%: 27\%) obtained by Walling (2013) from a collation of data for 84 UK rivers. However, the analysis is complicated by the fact that the OC content of soil decreases with depth, so that typically for UK soils, the subsoil OC concentration is only about one-fifth of the topsoil (Table S2, Figure S1). This would mean that to achieve the required amount of bulk subsoil OC to account for the $\mathrm{PO}^{14} \mathrm{C}$ values, the $\mathrm{SPM}$ fractions would have to be weighted towards the subsoil, which would not agree with Walling's results. A possible explanation is that soil components that are rich in organic matter are preferentially mobilised from the subsoil.

Another process that might explain why the riverine $\mathrm{PO}^{14} \mathrm{C}$ is depleted relative to topsoil (i.e. the average value of $91.2 \mathrm{pMC}$ in the 7 rural catchments) is preferential mineralisation within the river channel of radiocarbon-rich topsoil organic matter (Marwick et al., 2015). This could arise because topsoil contains organic matter pools with different 
turnover rates, and therefore with different ${ }^{14} \mathrm{C}$ contents. On this basis, Mills et al. (2014) used a steady-state model with two main organic carbon pools having mean residence times of 20 and 1000 years to interpret observed topsoil ${ }^{14} \mathrm{C}$ data, and estimated that the pools were present in roughly equal proportions. At the present time, the faster turnover pool has a ${ }^{14} \mathrm{C}$ content greater than $100 \mathrm{pMC}$ because of the presence of "bomb carbon", while the long-lived pool typically has a ${ }^{14} \mathrm{C}$ content of about $90 \mathrm{pMC}$. Furthermore, the topsoil contains plant litter deposited within the last few years, with a ${ }^{14} \mathrm{C}$ content slightly greater than $100 \mathrm{pMC}$. Both the litter and the 20-year major soil pool are mineralised in the terrestrial environment much faster than the 1000-year pool, and this difference would also be expected during riverine transport and temporary storage in the river bed. Loss of the more labile carbon would then reduce the $\mathrm{PO}^{14} \mathrm{C}$ value compared to that of topsoil. From regression analysis of UK-wide river data, Worrall et al. (2014) estimated that about $25 \%$ of POC is lost to the atmosphere as $\mathrm{CO}_{2}$ during riverine transport. If so, then a substantial reduction in the radiocarbon content of riverine POC could occur during transit. However, comparisons of sediment storage and annual flux suggest that residence times of SPM in UK rivers with catchment areas comparable to those of the present study are short, rarely more than a year (Owens et al., 1999; Collins and Walling, 2007), and so to achieve the $25 \%$ mineralisation loss suggested by Worrall et al. (2014), rates of decomposition of POC in rivers would need to be appreciably higher than is generally accepted for their turnover in the soil. Dispersion of the material and exposure to light during riverine transport might accelerate the mineralisation process.

A possible explanatory factor with respect to our results is the effect of parent geology, the importance of which was highlighted by Longworth et al. (2007) to interpret $\mathrm{PO}^{14} \mathrm{C}$ results for rivers draining small rural catchments in the Hudson-Mohawk watershed in upper New York State. Like our catchments, this is a low-erosion system as evidenced by the 5 -year average (2004-2008) [SPM] of $22 \mathrm{mg} \mathrm{L}^{-1}$ for the Mohawk River at Cohoes (http://waterdata.usgs.gov/nwis accessed April 2015). Longworth et al. (2007) did not report [SPM] and OC content of SPM, and so their results are absent from the plotted values of Marwick et al. (2015) in Figure 4. Generally, their $\mathrm{PO}^{14} \mathrm{C}$ values are higher than ours, falling in the range 89 to $109 \mathrm{pMC}$, but mostly they exceed $100 \mathrm{pMC}$. They explained the geographical distribution of their data, i.e. spatial variations in $\mathrm{PO}^{14} \mathrm{C}$ values, in terms of contributions to POM from the physical weathering of shale (containing organic matter low in ${ }^{14} \mathrm{C}$ ). However, this is an unlikely explanation for the relatively depleted $\mathrm{PO}^{14} \mathrm{C}$ reported in the present work, because the 7 rivers that provide the average of $91.2 \mathrm{pMC}$ are in catchments free 
of rock types containing ancient organic matter (Table 1). Therefore it seems unlikely that the presence of ancient carbon sources provides a general explanation for depleted $\mathrm{PO}^{14} \mathrm{C}$ in lowerosion catchments.

The present results fit with and extend the data compiled by Marwick et al. (2015). The plots in Figure 4 show that the global data fall into two zones. One occurs at high [SPM] and low $\mathrm{OC}$ content, for which very low ${ }^{14} \mathrm{C}$ values are observed, and the data encompass highly eroding, unstable systems (Smith et al., 2013). As noted by Marwick et al. (2015) this will reflect the strong dilution of topsoil-derived POC with eroded mineral matter low in OC but highly-aged, possibly with near-zero ${ }^{14} \mathrm{C}$. This zone occurs for [SPM] greater than about 100 $\mathrm{mg} \mathrm{L}^{-1}$ and for OC contents less than about $2 \%$. The other zone is for lower [SPM] and higher $\mathrm{OC}$ content and there appears to be no true trend in the $\mathrm{PO}^{14} \mathrm{C}$ values with either $[\mathrm{SPM}]$ or OC content in this range, especially after the addition of the new data presented here (Figure 4). Thus we find a range of $\mathrm{PO}^{14} \mathrm{C}$ between about 80 and $110 \mathrm{pMC}$ in the low-SPM, high-OC zone. Based on the present study and the conclusions of Marwick et al. (2015), variations in $\mathrm{PO}^{14} \mathrm{C}$ in low-erosion rivers can be attributed to variations in a number of factors. In approximate order of general importance these are (i) topsoil $\mathrm{O}^{14} \mathrm{C}$ variations across different land uses, (ii) catchment size and bank erosion, (iii) decomposition of POM during riverine transport, (iv) inputs of organic matter highly depleted in ${ }^{14} \mathrm{C}$ (from coal, shale or industry) and (v) in-river carbon fixation. Different combinations of these factors between rivers, or in the same rivers at different times, could generate the observed range of $\mathrm{PO}^{14} \mathrm{C}$ values. Progress towards the precise attribution of POC sources will require all these factors to borne in mind when designing field surveys and experiments. The fractionation of POM, e.g. by density or particle size, may also be a useful tool in characterising the $\mathrm{PO}^{14} \mathrm{C}$. In the meantime, modelling and forecasting future change in POC fluxes will only be approximate. However, it seems certain that the riverine transport of carbon fixed many centuries ago, arising from both topsoil and subsoil, is contributing appreciably to carbon budgets in the UK and other low-erosion locations, and will continue to do so.

The high degree of consistency among the rivers (Figure 2) means that the results presented here are probably representative of pasture and upland catchments of similar size or greater across the UK. Catchments dominated by arable agriculture are missing from this study and should be considered in future research. We would expect that their rivers would have lower $\mathrm{PO}^{14} \mathrm{C}$, in view of the available data on arable topsoils showing them to be relatively low in ${ }^{14} \mathrm{C}$ (Figure 3). The likely lower $\mathrm{PO}^{14} \mathrm{C}$ values in arable-dominated catchments, together 
441 with contributions of POC from catchments with coal mining and industry, will tend to make 442 the average age of POC entering the sea from the whole UK, somewhat greater than the average 443 value of $680{ }^{14} \mathrm{C}$ years derived for the rural catchments of the present study. 
- Particulate organic matter transported at high flow by 7 UK rivers draining pastoral rural landscapes had an average ${ }^{14} \mathrm{C}$ content of $91.2 \mathrm{pMC}$, corresponding to an apparent average age of $681{ }^{14} \mathrm{C}$ years. These rivers show no significant difference $(\mathrm{p}>0.05)$ in their average ${ }^{14} \mathrm{C}$ values.

- Owing to industrial and mining activity in its catchment, the River Calder's POM was significantly more depleted in ${ }^{14} \mathrm{C}$ (average $76.6 \mathrm{pMC}$ ). The Ribble $\mathrm{B}$ site, of which the River Calder is a tributary, also showed depleted $\mathrm{PO}^{14} \mathrm{C}$ as a result of the contribution from the Calder catchment.

454

- Erosion of topsoil is an obvious major source of riverine POM. The most likely explanations for the relatively low $\mathrm{PO}^{14} \mathrm{C}$ in the 7 rural rivers compared to topsoil $\mathrm{O}^{14} \mathrm{C}$ (range 94 - 109 pMC depending upon land-use) are firstly, inputs of older subsoil OC due to bank erosion and secondly, preferential mineralisation of ${ }^{14} \mathrm{C}$-rich organic matter during riverine transport.

- The present results are probably typical of other UK rivers with similar catchment soils and land uses. We expect that catchments dominated by arable soils would have lower $\mathrm{PO}^{14} \mathrm{C}$ values because of lower topsoil radiocarbon levels. 
The research was funded by the UK Natural Environment Research Council 466 Macronutrient Cycles Programme (LTLS project, Grant No. NE/J011533/1), and the Scottish

467 Government. We are grateful to A Panton (National Oceanography Centre, University of 468 Southampton), EC Rowe (CEH Bangor) and C Somerville for assistance with sampling, P 469 Scholefield (CEH Lancaster) for providing catchment area values, the analytical chemistry 470 teams at CEH Lancaster and the James Hutton Institute (Rural and Environment Science and 471 Analytical Services Division of the Scottish Government) for organic carbon measurements, 472 and K Howarth (Environment Agency, North-West England) for facilitating access to sampling 473 sites in the Ribble catchment. Thanks are due to the staff at the SUERC AMS Laboratory, 474 East Kilbride for carbon isotope measurements, and to Dr Xiaomei Xu at the Keck Carbon 475 Cycle AMS Laboratory, University of California, Irvine for analysis of three of the samples 476 (Table 3). 


\section{References}

Aufdenkampe AK, Mayorga E, Raymond PA, Melack JM, Doney SC, Alin SR, Aalto RE, Yoo, K (2011) Riverine coupling of biogeochemical cycles between land, oceans and atmosphere. Front Ecol Environ 9, 53-60 DOI: 10.1890/100014

Blair N, Leithold E, Ford ST, Peeler KA, Holmes JC, Perkey DW (2003) The persistence of memory: the fate of ancient sedimentary organic carbon in a modern sedimentary system. Geochim Cosmochim Acta 67, 63-73 DOI: 10.1016/S0016-7037(02)01043-8

Boutton TW, Wong W W, Hachey DL, Lee L S, Cabrera MP, Klein, PD (1983) Comparison of quartz and pyrex tubes for combustion of organic samples for stable carbon isotope analysis. Anal. Chem 55: 1832-1833. DOI: 10.1021/ac00261a049

Bouchez J, Galy V, Hilton RG, Gaillardet J, Moreira-Turcq P, Pérez MA, France-Lanord C, Maurice L (2014) Source, transport and fluxes of Amazon River particulate organic carbon: insights from river sediment depth profiles. Geochim Cosmochim Acta 133, 280-298 DOI: 10.1016/j.gca.2014.02.032

Cathalot C, Rabouille C, Tisnérat-Laborde N, Toussaint F, Kerhervé P, Buscail R, Loftis K, Sun M-Y, Tronczynski J, Azoury S, Lansard B, Treignier C, Pastor L and Tesi T (2013) The fate of river organic carbon in coastal areas: A study in the Rhône River delta using multiple isotopic $\left(\delta^{13} \mathrm{C}, \Delta^{14} \mathrm{C}\right)$ and organic tracers. Geochim Cosmochim Acta 118, 3355 DOI: 10.1016/j.gca.2013.05.001

Chapman AS, Foster IDL, Lees JA, Hodgkinson RA, Jackson RH (2001) Particulate phosphorus transport by sub-surface drainage from agricultural land in the UK. Environmental significance at the catchment and national scale. Sci Total Environ 226, 95-102 DOI: 10.1016/S0048-9697(00)00734-8

Collins AL, Walling DE (2007) Fine-grained bed sediment storage within the main channel systems of the Frome and Piddle catchments, Dorset, UK. Hydrol Process 21, 14481459 DOI: 10.1002/hyp.6269

Da Cunha LC, Serve L, Gadel F, Blazi JL (2000) Characterisation of riverine particulate organic matter by pyrolysis-gas chromatography-mass spectrometry. Sci Total Environ 256, 191-204

Deasy C, Brazier RE, Heathwaite AL, Hodgkinson R (2009) Pathways of runoff and sediment transfer in small agricultural catchments. Hydrol Proc 23, 1349-1358 DOI: 10.1002/hyp. 7257 
Estrany J, Garcia C, Walling DE (2010) an investigation of soil erosion and redistribution in a Mediterranean lowland agricultural catchment using caesium-137. Int'1 J Sediment Res 25, 1-16 DOI: 10.1016/S1001-6279(10)60023-6

Foster GD, Roberts Jr EC, Gruessner B, Velinsky DJ (2000) Hydrogeochemistry and transport of organic contaminants in an urban watershed of Chesapeake Bay (USA). Appl Geochem 15 901-915 DOI: 10.1016/S0883-2927(99)00107-9

Gaillardet J, Dupré B, Allègre CJ (1999) Geochemistry of large river suspended sediments: silicate weathering or recycling tracer? Geochim Cosmochim Acta 63, 4037-4051 DOI: 10.1016/S0016-7037(99)00307-5

Gruszowski KE, Foster IDL, Lees JA, Charlesworth SM (2003) Sediment sources and transport pathways in a rural catchment, Herefordshire, UK. Hydrol Proc 17 2665-2681 DOI: 10.1002/hyp.1296

Higueras M, Kerhervé P, Sanchez-Vidal A, Calafat A, Ludwig W, Verdoit-Jarraya M, Heussner S, Canals M (2014) Biogeochemical characterization of the riverine particulate organic matter transferred to the NW Mediterranean Sea. Biogeosciences 11, 157-172 DOI: 10.5194/bg-11-157-2014

Hilton RG, Galy A, Hovius N, Chen M-C, Horng M-J, Chen H (2008) Tropical-cyclone-driven erosion of the terrestrial biosphere from mountains. Nature Geoscience 1, 759-762 DOI: $10.1038 /$ ngeo333

Hua Q, Barbetti M, Rakowski AZ (2013) Atmospheric radiocarbon for the period 1950-2010. Radiocarbon 55, 2059-2072.

Ittekot V, Laane RWPM (1991) Fate of riverine particulate organic matter. Biogeochemistry of Major World Rivers, Scope 42 edited by E.T. Degens, S. Kempe, and J.E. Richey, John Wiley, Chichester

Jenkinson DS, Poulton PR, Bryant C (2008) The turnover of organic carbon in subsoils. Part 1. Natural and bomb radiocarbon in soil profiles from the Rothamsted long-term field experiments. European Journal of Soil Science 59, 391-399

Kendall C, Silva SR, Kelly VJ (2001) Carbon and nitrogen isotopic compositions of particulate organic matter in four large river systems across the United States. Hydrol Proc 15, 1301-1346 DOI: 10.1002/hyp.216

Klages MG, Hsieh YP (1975) Suspended solids carried by the Gallatin River of southwestern Montanna: II. Using mineralogy for inferring sources. J Environ Qual 4, 68-73 DOI: $10.2134 /$ jeq1975.00472425000400010016x 
Longworth BE, Petsch ST, Raymond PA, Bauer JE (2007) Linking lithology and land use to sources of dissolved and particulate organic matter in headwaters of a temperate, passive-margin river system. Geochim Cosmochim Ac 71 4233-4250 DOI: 10.1016/j.gca.2007.06.056

Lu YH, Bauer JE, Canuel EA, Chambers RM, Yamashita Y, Jaffé R, Barrett A (2014) Effects of land use on sources and ages of inorganic and organic carbon in temperate headwater streams. Biogeochemistry 119, 275-292 DOI:10.1007/s10533-014-9965-2

Marwick TR, Tamooh R, Teodoru CR, Borges AV, Darchambeau F and Bouillon S (2015) The age of river-transported carbon: A global perspective. Global Biogeochem Cy 29, 122-137 DOI: 10.1002/2014GB004911

Megens L, van der Plicht J, de Leeuw JW (2001) Temporal variations in ${ }^{13} \mathrm{C}$ and ${ }^{14} \mathrm{C}$ concentrations in particulate organic matter from the southern North Sea. Geochim Cosmochim Acta 65, 2899-2911.

Meybeck M (1982) Carbon, nitrogen and phosphorus transport by world rivers. Am J Sci 282, $401-450$

Mills RTE, Tipping E, Bryant CL, Emmett BE (2013) Long term organic carbon turnover rates in natural and semi-natural topsoils. Biogeochemistry 118, 257-272 DOI: $10.1007 / \mathrm{s} 10533-013-9928-\mathrm{z}$

Onstad GD, Canfield DE, Quay PD, Hedges JI (2000) Sources of particulate organic matter in rivers from the continental USA: lignin phenol and stable carbon isotope compositions. Geochim Cosmochim Acta 64, 3539-3546

Owens PN, Walling DE, Leeks GJL (1999) Deposition and storage of fine-grained sediment within the main channel system of the River Tweed, Scotland. Earth Surf Process Landforms 24, 1061-1076

Raymond P, Bauer J (2001) Use of ${ }^{14} \mathrm{C}$ and ${ }^{13} \mathrm{C}$ natural abundances for evaluating riverine, estuarine, and coastal DOC and POC sources and cycling: a review and synthesis. Org Geochem 32 469-485 DOI: 10.1016/S0146-6380(00)00190-X

Rosenheim B, Galy V (2012) Direct measurement of riverine particulate organic carbon age structure. Geophys Res Lett 39 n/a-n/a DOI: 10.1029/2012GL052883

Schlünz B and Schneider (2000) Transport of terrestrial organic carbon to the oceans by rivers: re-estimating flux- and burial rates. Int J Earth Sci 88, 599-606 DOI: $10.1007 / \mathrm{s} 005310050290$ 
Slota Jr PJ (1987) Preparation of small samples for ${ }^{14} \mathrm{C}$ accelerator targets by catalytic reduction of CO. Radiocarbon 29, 303-306

Smith JC, Galy A, Hovius N, Tye AM, Turowski JM, Schleppi P (2013) Runoff-driven export of particulate organic carbon from soil in temperate forested uplands. Earth Planet Sc Lett 365, 198-208 DOI: 10.1016/j.eps1.2013.01.027

Stuiver M, Polach HA (1977) Reporting of ${ }^{14} \mathrm{C}$ data. Radiocarbon 19, 355-363

Tipping E, Marker AFH, Butterwick C, Collett GD, Cranwell PA, Ingram JKG, Leach DV, Lishman JP, Pinder AC, Rigg E, Simon BM (1997) Organic carbon in the Humber rivers. Sci Total Environ 194/195, 345-355 DOI: 10.1016/S0048-9697(96)05374-0

Trumbore S (2009) Radiocarbon and soil carbon dynamics. Annual Rev Earth P1 Sc 37, 47-66 DOI: 10.1146/annurev.earth.36.031207.124300

Walling DE (2005) Tracing suspended sediment sources in catchments and river systems. Sci Tot Environ 344, 159-184 DOI: 10.1016/j.scitotenv.2005.02.011

Walling DE (2013) Sediment source: a key parameter of catchment sediment yield In: Advances in River Sediment Research, Proc. 12th International Symposium on River Sedimentation, ISRS 2013, Kyoto, Japan, September 2013 (Eds. S. Fukuoka, H Nakagawa, S. Tetsuya and H. Zhang) CRC Press, 37-47

Worrall F, Burt TP, Howden NJK (2014) The fluvial flux of particulate organic matter from the UK: quantifying in-stream losses and carbon sinks. J Hydrol 519, 611-625

Xu S, Anderson R, Bryant C, Cook GT, Dougans A, Freeman S, Naysmith P, Schnabel C, Scott EM (2004) Capibilities of the new SUERC 5MV AMS facility for ${ }^{14} \mathrm{C}$ dating. Radiocarbon 46, 59-64 